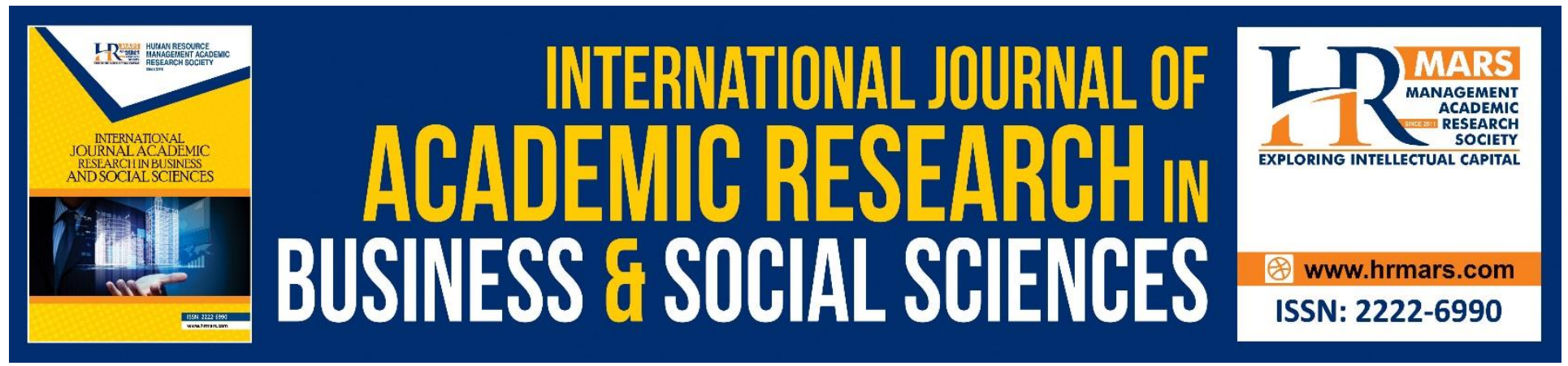

\title{
Holistic Methods to the Formation of Integrity: Their Significance in Civilizing the Community by Imam Al-Juwayni
}

Mohd Fadzhil Mustafa, Mohamad Sabri Haron, Mohamad Zaidin Mohamad, Mohd Hasrul Shuhari, Omar S.H.S., Wan Mohd Khairul Firdaus Wan Khairuldin

To Link this Article: http://dx.doi.org/10.6007/IJARBSS/v8-i10/4713

DOI: $10.6007 /$ IJARBSS/v8-i10/4713

Received: 18 Sept 2018, Revised: 13 Oct 2018, Accepted: 16 Oct 2018

Published Online: 30 October 2018

In-Text Citation: (Mustafa et al., 2018)

To Cite this Article: Mustafa, M. F., Haron, M. S., Mohamad, M. Z., Shuhari, M. H., S.H.S, O., \& Khairuldin, W. M. K. F. W. (2018). Holistic Methods to the Formation of Integrity: Their Significance in Civilizing the Community by Imam Al-Juwayni. International Journal of Academic Research in Business and Social Sciences, 8(10), 7383.

Copyright: (C) 2018 The Author(s)

Published by Human Resource Management Academic Research Society (www.hrmars.com)

This article is published under the Creative Commons Attribution (CC BY 4.0) license. Anyone may reproduce, distribute, translate and create derivative works of this article (for both commercial and non-commercial purposes), subject to full attribution to the original publication and authors. The full terms of this license may be seen at: http://creativecommons.org/licences/by/4.0/legalcode

Vol. 8, No. 10, 2018, Pg. $73-83$

Full Terms \& Conditions of access and use can be found at http://hrmars.com/index.php/pages/detail/publication-ethics 


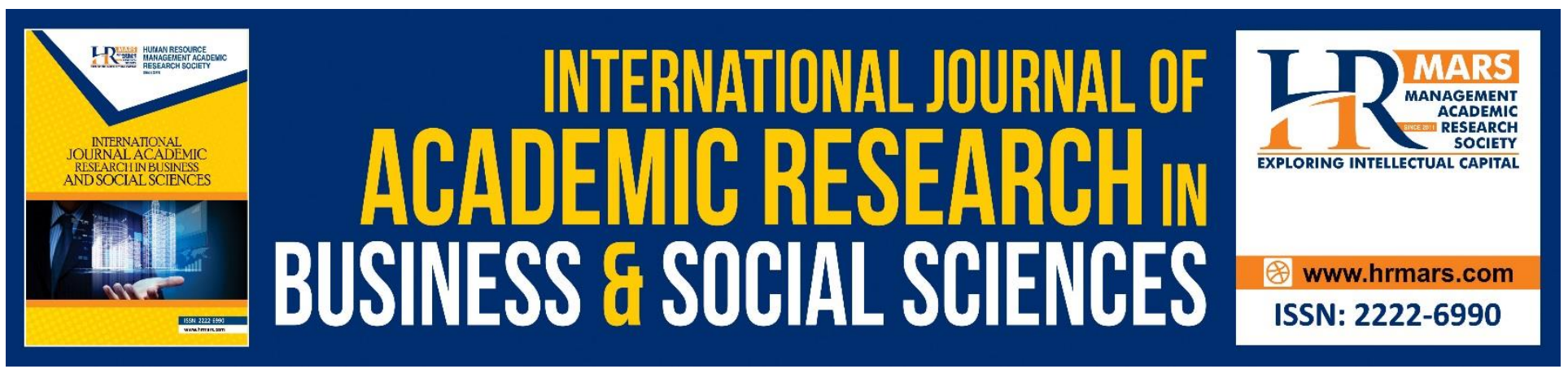

\title{
Holistic Methods to the Formation of Integrity: their Significance in Civilizing the Community by Imam Al- Juwayni
}

\author{
Mohd Fadzhil Mustafa \\ University of Sultan Zainal Abidin (UniSZA), Malaysia \\ Email: fadzhil@unisza.edu.my
}

Mohamad Sabri Haron

National University of Malaysia

\author{
Mohamad Zaidin Mohamad, Mohd Hasrul Shuhari, \\ Omar S.H.S., Wan Mohd Khairul Firdaus Wan Khairuldin \\ University of Sultan Zainal Abidin, (UniSZA), Malaysia
}

\begin{abstract}
This paper aims to shed light on the integrity value ideas that were specifically developed by Imam al-Juwayni since the fifth decade in the Hijri calendar through a holistic usuli thought method. It indeed has become a universal need throughout the time to realize the civilization of humankind in achieving the prosperity of life in the world and hereafter. Nowadays, our society is often blamed and scapegoated when such bad phenomena as bribery, abuse of power as well as the confusion in actions and behaviors occur thus deviating them from the true path of life. Therefore, Islam always nurtures and promotes the value ideas that should be practiced in comprehensive life of humankind. Some prominent figures in Islam have emerged to recommend some integrity values in order to form understanding besides elevating the quality of behaviors among the community members effectively. One of the figures who proposed the usuli method is Imam al-Juwayni. Based on a qualitative research including the historical studies and content analysis, the writer will illustrate some methods that are successfully used in gaining knowledge, understanding, awareness, wisdom and their appreciation. In this case, Imam al-Juwayni has been recognized to successfully outline the integrity value ideas as a practical system in creating the excellent generation.
\end{abstract}

Keywords: Integrity Value Ideas, Imam Al-Juwayni's Methods, Wisdom, The Excellent Generation. 


\section{INTRODUCTION}

The method in determining laws and values based on the consistent and transparent concept of sibgha ilahiyya has been introduced by Imam al-Juwayni. Sibgha ilahiyya is the spark as the result of the God's blessing that covers three important elements in human, namely tawhid (Islamic theology), morals (noble morals) and fiqh (implementation of law/values). It covers ahkam al-ilahiyyat with the nature of qur'anic, mawsu'ic and ijtihadic (al-Durayni, 1997). It subsequently makes the process of studies much easier in extracting the syariat laws related to the implementation of taklif shara' and the achievement of maqasid shariah in its specific and general forms. In this case, there are five categories of dawabit, the usuli thoughts that can be applied holistically as the result of the sibgha ilahiyya. Dawabit in this study, according to the writer, can be perceived as the universal methods, borderlines, measurement standard or stringent conditions. The five categories of dawabit are: taklif shara', maslahah, istidlal, illat hukm al-asl and ta'arud between the nas (essence).

The rationale in choosing these five categories is because they influence the situation, position, process and the creation of laws or values that want to be solved by the mujtahid or the moslem scholars who have expertise in issuing laws. This can be materialized if there is or there is no very clear explanation through al-Qur'an and al-Sunnah. In other words, it can happen either in qat'i or zanni way, for example; the difference in maslahah between an individual and the congregation. The same goes to the case when there are differences among the mukallaf themselves. These matters will involve the status of reception or rejection towards the laws based on the mistakes or khilaf that might happen. Meanwhile, the mujtahid will judge and evaluate based on their respective dawabit. All these issues need a solution with dignity to retain the holiness of the Islamic laws as well as to fulfill the demand of the implementation of taklif shara' and the achievement of maqasid shariah.

In conjunction with the matter, there are some mechanisms made to achieve the scope and pinnacle of the ilm, especially the values of ilm al-din that can form someone by having good personality with high integrity level. One method used by Imam al-Juwayni is taqsim (dividing/sectioning) since it can form a very solid and consistent dawabit (J. Milton Cowan, 1980, page 763. Therefore, Imam al-Juwayni (1991) mentioned three main mediums that can help the process of creating dawabit, for examples; al-uqul (ma'rifa or knowledge), al-murshid ila thubut kalam sidq (murabbi or teacher) and adillat al-sam'iyyat (God revelation).

\section{JUSTIFICATION OF IMAM AL-JUWAYNI IN MALAYSIA}

One of the greatest intellectual figures that can be referred to as example of taqwa (courtesy) and integrity is Imam al-Juwayni or Imam al-Haramayn. Both names are given to Abdul Malik ibn Abdullah ibn Yusof ibn Abdullah ibn Yusof ibn Muhammad ibn Hayyuyah al-Juwayni al-Naysaburi (1028-1085 AD). Juwayn is a village located in the district of Naysabur in northern Iran. It is well known as a recreational and tourist place as well as the farming valley located between two hills. Its opening has been completed by Yazid al-Jurshi in $28 \mathrm{AD}$. He has been sent by the governor of Basrah by the name of Abdullah ibn Amir ibn Kurayz during the reign of Khalifah Uthman ibn Affan. Imam al-Juwayni has successfully developed a new dimension in contemporary school of thought that leads to the development of human capital and life-long learning. The justification in choosing him in the 
Malaysian context is because he is an imam (expert for reference) from an Arab descendant who is well-known internationally thus labeling him as Imam al-Haramayn (expert for reference both in Mecca and Medina). However, he comes from the ideology of Shafi'i that is very dominant in Malaysia. He is one of the leaders of al-Shafi'iyyah in Naysabur (Musa \& Mun'im, 1950). He was also appointed as an officer of hisbah (monitoring and enforcement) under the instruction of Minister Nizam al-Malik (al-Juwayni, 1990, page: 9). His task was to monitor the implementation of rules and regulations in Syariah laws and manifestation of the values of taqwa during the reign of Sultan Alab Arsalan to ensure that they were practiced in the grassroots level (IbnKhalkan, 1949; al-Subki, 1964).

Imam al-Juwayni also made a lot of studies (nazar) as well as analyzed (tahqiq) an issue deeply by using his intuition and intellectuality (basirah). This can be further seen and observed in this research through the method in conducting taklif shara' and the achievement of maqasid shariah. The issue of integrity values that were developed by Imam al-Juwayni was raised as well as the relationship between the dawabit of his jurisprudence thoughts with the formation of human capital integrity model. Besides, it is important to see the suitability of the method in forming the integrity value ideas comprehensively and transparently in Malaysia.

\section{INTEGRITY VALUE IDEAS}

The following ideas are some of the integrity values according to dawabit taklif shara', dawabit maslahah, dawabit istidlal, dawabit illat hukm al-asl and dawabit ta'arud between nas (essence).

\section{Having ilm (knowledge) and adding ma'rifa (great knowledge)}

In general, ilm and ma'rifa are integrity values that must be taken seriously by every normal person in order to achieve the level of maqasid or maslahah in accordance with the syarak (Islamic law). Besides, they can strengthen everyone's behaviors and attitudes in the eyes of the society since both of them are the pinnacle of revelation that can be achieved by everyone. The law of learning ilm is compulsory on male and female Moslems. Imam al-Juwayni (1991) gave some definitions on ilm according to the Moslem scholars as follows:

i) Tabayyun al-ma'lum: to research or study matters or any known information (al-Juwayni, 1991).

ii) Something that results in the owner deemed as alim (Shaykh Abu al-Hasan al-Ash'ari r.a). Abu al-Hasan al-Ash'ari is Ali bin Ismail bin Abu Bisyr Ishaq bin Salim bin Abu Musa alAsh'ari. He has upheld the hujja (completion of proof) to involve al-sunnah. He passed away in 334 AD (al-Juwayni, 1991; Ibn Kathir, 1989).

iii) Something which is legally possessed will be able to strengthen and improve the deeds and behaviors of someone (al-Ustaz Abu Bakar bin Fawrak). Abu Bakar bin Fawrak is Ahmad bin Musa bin Mardawayh al-Asbahani is a hafiz and an Islamic scholar in usul who was also good in hadith. He narrated from Abu Sahl bin Zayyad al-Qattan and many more. He passed away in 410 AD (Taqiyyuddin, 1987).

iv) The Muktazilah group give definition of $i \mathrm{~lm}$ (knowledge) that is to believe in something according to the real truth through a peaceful soul. 
That is why, the truth on ilm that is understood from the words of Imam al-Juwayni is a selfappreciation towards the meaning of inshirah, thalj and thiqah. The concept of ilm, in general, can be the catalyst to the solution of every problem involving thoughts or principles of life by every person. Imam al-Juwayni (1991) further explained the concept:

ilm describes the shedding light of the bonds (problems) since it makes us have the feeling of relieved, comfortable and self-confident.

Therefore, ilm is not only information, but also a process of generating to the pillar or the base. That is why ilm is a way, method or values of life. Through the ilm, we will be able to identify some methods that can inform some spectacular inventions of the individual level, inventions of materials and journey of life (Subhi, 1982). Some of the values that every person with high knowledge must have are:

1) Can identify the weaknesses or mistakes of the parties who try to mislead him/her.

2) Firmly believe in anything known by him/her.

3) Calm and always feeling relieved to refuse any doubts that are raised.

4) Making or asking for any explanation on any doubts that are raised with soft voice and appropriate words.

5) Inviting the opponents to have a dialogue and discuss by using good and polite manners.

\section{Allowing Mu'jizat}

The meaning of mu'jizat from the linguistic point of view is fawt (going beyond) and sabq (passing). al-Sayuti (1979) had given the definition as a matter of breaking the tradition, with some challenges, safe from some resistance and disclosed by God the Almighty (Allah S.W.T) through the powers owned by His prophets or messengers. That is why, the writer opines that the meaning of enabling the mu'jizat is to recognize the truth of matter (qarinat) that exists beyond the sunnah that has been created by Allah S.W.T to this universe (qarinat haliyya). It happens because the qarinat is not bound and bowed to the normal causal matter. None of the normal humankind can reach the level of $m u$ 'jizat even though with his endless efforts except by the permission of Allah. The qarinat is merely the reward from Allah who chooses the type and time when it happens to prove the truth brought by His messengers in spreading the message of Islam (Muslim, 2008).

In his work entitled al-Burhan, Imam al-Juwayni has repeated the word mu'jizat for 31 times, especially when he discusses things related to madarik al-ulum fi al-din. Besides, he also describes that the concept of mu'jizat must be understood in the context of reasoning of the knowledge intrinsically. To him, mu'jizat is described as an action (kun fayakun) that solely belongs to Allah, breaking the tradition, and appeared as a request from someone deemed himself as a prophet. Normally, it is impossible to happen to normal or common people even though they try hard to do so. In this case, al-Juwayni (1991) mentioned: 
The second theory for the affirmation of the concept of mu'jizat is the truth of the prophets that have been bestowed with mu'jizat. Although there is no time to describe conditions and their laws perfectly, our objective here is to illustrate that the $m u^{\prime} j i z a t$ is an action that solely belongs to Allah, breaking the tradition. Besides, It will not happen to others even though they try to make resistance. The clues for $m u^{\prime} j i z a t$ are closely related to the description of qarinat haliyya that are related to knowledge of badihiyyat.

\section{Values of ta'abbudi through khushu' and tawadu'}

al-Juwayni (1991) has categorized the laws to two parts. Firstly, ma yu'allal, that is the law that has attributes or reasons (illat) behind it. Secondly, ma la yu'allal or having attribute of ta'abbudi (to make someone have an attribute of being tawadu' that is humble, submission to god, adheres to taklif shara'. Mustafa et. al. (1990), that is the law that has no reasons (illat) behind it but it is still implemented. On the value of $t a^{\prime} a b b u d i$, he stated:

The Messenger of Allah or Prophet Muhammad P.B.U.H is one of the muta'abbid (doing ibadat) with matters related to taklif (task division) the same as other Moslems. If anyone says that it is because of its values, this is hadhayan (false) because according to the dignity of essence, taklif (task division) will become a specific item for matters of their rights. However, the involvement of values in some occasions will not get them rid of from the laws shared by the community. Moreover, the value is too little compared to the general laws. That is why every type of human being will undergo their own processes or levels according to their specific values. For example, women will become specific before the laws compared to men. Likewise, for those who are travelling or on journey, they are bound with specific law of journey which is different from people who are permanently staying or residing somewhere. The same goes to the asnaf (variety) of mukallaf or adults who are bound to practice the religious teaching.

Imam al-Juwayni explained the true meaning of ta'abbudi according to the Islamic law. He clearly used the term ta'abbudi for 55 times in some different places in the al-Burhan. This shows that the law in the form of ta'abbudi cannot have any illat or reason on its laws, but it must be implemented with humility and humbleness. Some examples of the ta'abbudi values as mentioned by Imam al-Juwayni are:

If the prophet Muhammad brought the Islamic laws, he was focused to explain the law, the basis of the Islamic law and explanation of the features of $t a^{\prime} a b b u d i$. This is something compulsory to do. For those who zan (think of) something different from what has been explained, they must blame themselves. Imam Shafi'i mentioned about hadith narrators who narrated from the prophet Muhammad that the prophet decided on the rights of properties based on the witness and the pronounced oath; he said: this theory has its specific place as 
narrated since the pronouncement does not show the general laws. In this case, any qiyas (the teachings of the hadith are compared and contrasted with those of the Qur'an) cannot be used to face up with the dignity of bayyinat (evidence) since their position is based on the values of ta'abbudi.

\section{Entertaining human's ability}

Actually, there is no any conflict or dispute on the term rabbani (divine) with the term insani (human) in the measurement of value. These two terms deal with each other very closely. This happens because the basis of rabbani exists in the human nature. Generally, every born baby to this world is deemed as having a basic nature, which is Islamic nature that brings the notion of full submission and humbleness to the God Almighty (al-Qaradawi, 2002).

The values in entertaining the ability of the human that is very limited is so significant since the main objective of the Islamic law is to live a better life based on the basic principles and elements of human. It needs to be entertained in line with their ability, starting from a child to an adult, with regard to their health state; sick or healthy, weak or strong, in joyfulness or hardship or whether someone lives as an individual or lives in a group. Therefore, every human is given the same chance to fulfill their wish and maslahah (public interest) that are granted by the Islamic law. Besides, one also has to look after their life by adhering to what is commanded by Allah and having good personal traits by practicing taklif shara' and their duties towards the God, themselves, family, Islam followers and human kind in general (al-Qaradawi, 2002).

Imam al-Juwayni stressed out that the ability of a human in implementing taklif shara' must be entertained in order to preserve karamah (dignity) of the human and their mind. The rationale is that, their position is noble and high that can overcome other creatures. In this case, Imam al-Juwayni (1991) said:

If you are asked, what is sound in your side on taklif ma la yutaq (impaired or disabled duties)? We answer: if it is meant to be with the taklif or talab al-fi'l (the demand to do), that is ma la yutaq which is impossible because what is demanded is very unlikely to happen. Conversely, if it is needed with wurud al-sigha (pronouncement only) and it does not mean talab (demand), as the word of God (al-Qur'an, al-Baqarah 2: 65) that means: Be you monkey, despised and rejected, this does not matter since the meaning of the sigha is We (Allah Glorious and exalted is $\mathrm{He}$ ) has made them the despised and rejected monkeys, so it happens to them as We wish.

\section{HOLISTIC METHODS OF IMAM AL-JUWAYNI}

The taqsim method is one of the theories using thoughts between nafy and ithbat and has become practice in the genuine nazar or vow. It happens since the theories based on thoughts are divided into four categories (al-Juwayni 1997): 
INTERNATIONAL JOURNAL OF ACADEMIC RESEARCH IN BUSINESS AND SOCIAL SCIENCES Vol. 8, No. 10, Oct. 2018, E-ISSN: 2222-6990 @ 2018 HRMARS

a) Shedding light on ghayb (ignorance) based on shahid (verification).

b) Muqaddimat (The Essentials of Islamic Philosophy) that produces certain outcomes.

c) Methods of sabr and taqsim.

d) Doing istidlal (to try looking for theories or the source of the laws that are still not known their source) using theories that are agreed towards a disputed theory.

Below are classical expressions made by Imam al-Juwayni on the application of burhan, taqsim and istidlal.

If an engineer builds an introduction in the form of diagram and then reveals with certain claims and are proved by basing on the introduction, so he needs to think it over in order to get the findings or outcomes. If he masters what he is looking for, so the knowledge he possesses is based on the notion of the introduction. The same goes to the discussion on adadiyyat (number of digits).

Great writers often mention about jism sakin if it moves, so new thing will happen whereby it has never happened before. This is targeted without any nazar or vow. If his thought is correct from the perspective of ithbat al-a'rad (attribute), so he says: is this new thing compulsory or not? He then uses taqsim between nafy and ithbat, and then thinks either for a short or long time using the sharpness of his mind and his potential and he knows without any wasilah (an action to make us nearer to the thing we wish) and theory that by deciding that something must move is impossible. That is why the law used here is mubah (option). And then another new taqsim appears that asks whether any known matter involves in its substance or not. He then thinks again till the involvement is one of the law deemed daruri.

If the matter is certain, the dawabit of the objective of this fas/ states that everything focused with consistent taqsim, although it is rather heavy and difficult to determine any one of them (nazari and daruri), so that is something that can still be explored by the intellect. If a taqsim is not consistent or may be consistent, but the view of the intellect does not meet its illat, even though through a long contemplation, so this is deemed as beyond the human intellect.

In conjunction with the matter, the method of istinbat of the law (to determine the Islamic law in accordance with theories in al-Qur'an and al-sunnah) which is applied holistically can smoothen the formulation of dawabit as well as create law and values. According to the work of al-burhan, the concept of istinbat is known as istidlal. That is why Imam al-Juwayni (1991) has set the concept of istidlal in the context of same meaning or illat that describes the laws that are suitable in accordance with the occurrence of thought without any agreed theory. He then added illat that is used as the basis of the law has actually been part of the istidlal. His unique expressions were recorded as follows:

All great Moslem scholars and the imams deemed as mujtahid have disagreed on istidlal, meanwhile it indeed has the same illat that describes the laws that are suitable for them in 
INTERNATIONAL JOURNAL OF ACADEMIC RESEARCH IN BUSINESS AND SOCIAL SCIENCES

Vol. 8, No. 10, Oct. 2018, E-ISSN: 2222-6990 @ 2018 HRMARS

accordance with the intellect without any agreed theory. And the illat that is upheld has been implemented in the laws.

\section{THE SIGNIFICANCE OF METHOD OF IMAM AL-JUWAYNI IN THE CONTEXT OF INCULCATING THE CONTEMPORARY INTEGRITY VALUES}

The writer thinks that every value has its own strength and its respective formation base. The rationale is since it can be achieved by the intellect and practiced by every individual in planning their life in an institution or an organization. For this reason, the values can be used as pushing and driving factors within the individuals efficiently. At the same time, the values are able to form behaviors and encompass the direction of the individual to achieve a goal or a desired aspiration (Ismail \& Hussin, 2007). Some examples of these values are contained in the twelve pillars of National Institute of Public Administration (1994). The twelve pillars are as follows:
i. The value of time
ii. The success of perseverance
iii. The pleasure of working
iv. The dignity of simplicity
v. The worth of character
vi. The power of kindness
vii. The influences of examples
viii. The obligation of duty
ix. The wisdom of economy
$x$. The virtue of patience
xi. The improvement of talent
xii. The enjoyment of creation

More interestingly, there is another profile of civil servant deemed as jauhari or thinking and talented civil servants for the success of the country in the future. Kang et. al. (2009) illustrated a diagram of the profile of civil servants needed by the country. The profile has been divided into two categories, namely the development of competence and the development of relevance. The development of competence itself is divided into two value dimensions, namely core and professional. Meanwhile, the development of relevance is divided into two other dimensions namely capacity and expansion.

Thinking and Talented Civil Servants

\begin{tabular}{|c|c|c|c|}
\hline Core & Professional & Capacity & Expansion \\
\hline $\begin{array}{ll}\text { - } & \text { Attitude } \\
\text { - } & \text { Motivation } \\
\text { - } & \text { Discipline } \\
\text { - } & \text { Integrity }\end{array}$ & $\begin{array}{ll}\text { - } & \text { Cognitive } \\
\text { - } & \text { Knowledge } \\
\text { - } & \text { Skills } \\
\text { - } & \text { Communication } \\
\text { - } & \text { Teamwork }\end{array}$ & $\begin{array}{ll}\text { - } & \text { Customer- } \\
\text { oriented } \\
\text { - } & \text { High quality } \\
\text { - } & \text { High } \\
\text { - } & \text { achievement } \\
\text { Competitive }\end{array}$ & $\begin{array}{ll} & \text { Visionary } \\
\text { (forward looking) } \\
\text { - } & \text { Creative and } \\
& \text { innovative } \\
\text { - } & \text { Entrepreneurships } \\
\text { - } & \text { Partnerships }\end{array}$ \\
\hline
\end{tabular}

Source : Ooi Seong Kang, et. al. 
Therefore, the Tenth Malaysia Plan has used a theme "transformation towards a high income and advanced nation, resilient and competitive" that is supported by for basic values as complements for the civilization. Those values are:

- To inculcate the culture of creativity and innovation

- To prioritize on fast action and decision making

- Value for Money

- Integrity Values

According to Hoon et. al. (2011), the categories of those values have been successfully combined and integrated into seven fields which aim at guiding the life of the multi-racial society and subsequently enhance the unity of the nation state in Malaysia. The seven fields mentioned are as follows:

a) Values related to personal development

b) Values related to family or kinship

c) Values related to environment

d) Values related to patriotism

e) Values related to human rights

f) Values related to democracy

g) Values related to security and harmony

\section{CONCLUSION}

Generally, the research on the method of thoughts of Imam al-Juwayni in Malaysia has greatly given impacts towards the birth and existence of the integrity value ideas, especially in implementing them in the context of Malaysia society. It also proves the validity and reliability of dawabit of thoughts from Imam al-Juwayni that are sourced from the true divine revelation. Guided by some features of dignity as well as flexible methods through consistent dawabit categories, many issues related to the laws and the values of contemporary laws can be solved effectively. The relationship between the concepts of sibgha ilahiyya, holistic method with the birth and existence of value ideas that lead to the creation of excellent generation model collectively is very significant and relevant. Therefore, the meaningful and invaluable contributions from Imam al-Juwayni should be recommended to be evaluation reference, standard measure or the best model example to the current and future generation. All good things about these value ideas can be crystallized and implemented if every mukallaf (a Moslem bound to adhere to the true Islamic teachings) can appreciate the blessing of $i l m$, ma'rifa as well as having strength of high level of basirah (insights). These things will be obtained through implementing taklif shara' with diligence and sincerity besides achieving maqasid shari'ah earnestly.

\section{ACKNOWLEDGEMENT}

This article is part of a research fund sponsored and managed by the Center for Research and Innovation (RMIC), Sultan Zainal Abidin University (UniSZA), Gong Badak Campus 21300 Kuala Nerus, Terengganu, Malaysia. 
INTERNATIONAL JOURNAL OF ACADEMIC RESEARCH IN BUSINESS AND SOCIAL SCIENCES

Vol. 8, No. 10, Oct. 2018, E-ISSN: 2222-6990 ㄷ 2018 HRMARS

\section{REFERENCES}

Al-Quran al-Karim.

Latif, A. (1993), Manhaj Imam al-Haramayn fi Dirasat al-Aqidah, al-Riyad: Markaz al-Malik Faysal.

Al-Badawi, Y. A. M. (2000), Maqasid al-Shariah 'ind Ibn Taymiyyah, Amman: Dar al-Nafais.

Al-Dib, A. A. M. (1981). Imam al-Haramayn Abu al-Ma'ali Abdul Malik bin Abdullah al-Juwayni: Hayatuhu wa 'Asruhu, atharuhu wa fikruhu. Kuwayt: Dar al-Qalam.

Al-Dib, A. A. M. (1988). Fiqh Imam al-Haramayn Abdul Malik bin Abdullah al-Juwayni: Khasaisuhu, atharuhu, manzilatuhu. Mansurah: Matabi' al-Wafa'.

Al-Durayni, M. F. (1997). Al-Manahij al-Usuliyyah fi al-ljtihad bi al-Ra'y fi al-Tashri' al-Islami. Beirut: Muassasat al-Risalah.

Harbi, M. (1986), Imam al-Haramayn Abu al-Ma'ali al-Juwayni waatharuhu fi IIm al-Kalam. Beirut: 'Alam al-Kutub.

Al-Juwayni, A. M. A. (1978). Al-Aqidah al-Nizamiyyah fi al-Arkan al-Islamiyyah. Kaherah: Maktabat alKulliyah al-Azhariyyah.

Al-Juwayni, A. M. A. (1979). Ghiyath al-Umam fi Iltiyathi al-Zulam. Qatar: al-Shu'un al-Diniyyah.

Al-Juwayni, A. M. A. (1990). Ghiyath al-Umam fi Iltiyathi al-Zulam. Iskandariyyah: Dar al-Da'wah.

Al-Juwayni, A. M. A. (1991). Al-Burhan fi Usul al-Fiqh. Mansurah: Dar al-Wafa'.

Al-Juwayni, A. M. A. (1996). Kitab al-Talkhis fi Usul al-Fiqh. Beirut: Dar al-Basha'ir al-Islamiyyah.

Al-Juwayni, A. M. A. (1997). Ghiyath al-Umam fi Iltiyathi al-Zulam. Beirut: Dar al-Kutub al-Islamiyyah.

Al-Juwayni, A. M. A. (1997). Al-Burhan fi Usul al-Fiqh. Beirut: Dar al-Kutub al-cilmiyyah.

Al-Juwayni, A. M. A. (2003). Al-Talkhis fi Usul al-Fiqh. Lubnan: Dar al-Kutub al-cilmiyyah.

Al-Juwayni, A. M. A., (2007). Nihayat al-Matlab. Jeddah: Dar al-Minhaj.

Mahmud, F. (1987), Luma' al-Adillah fi Qawa'id Aqaid Ahli al-Sunnah wa al-Jamaah, Beirut: 'Alam alKutub.

Al-Zuhayli, M. (1992), al-Imam al-Juwayni Imam al-Haramayn, Dimasyq: Dar al-Qalam. 